\title{
DETERMINATION OF NI(II) IN ALLOYS USING A NEW REAGENT DERIVED FROM L-DOPA
}

Wagner José Barreto*+, Herica Aparecida Magosso*, Miriam Fátima Soares*, Bruno Marco Oliveira Silveira*, Ieda Spacino Scarminio ${ }^{+}$, Dílson Norio Ishikawa**, Sônia Regina Giancoli Barreto*

*Laboratory of Environmental Physical Chemistry, Department of Chemistry, CCE, Londrina State University, Londrina, PR, 86051990, Brazil.

${ }^{+}$Laboratory of Chemometrics in Natural Sciences, Department of Chemistry, CCE, Londrina State University, Londrina, CP 6001, 86051-990, Brazil.

**Department of Chemistry, CCE, Londrina State University, Londrina, CP 6001, 86051-990, Brazil

+barreto@uel.br

Abstract: A simple and sensitive UV-Vis spectrophotometric method was developed using a new chromogenic reagent, L-dopasemiquinone, for the quantification of $\mathrm{Ni}(\mathrm{II})$ in metallic alloys: Inox, Co-Cr, and Ni-Ti. The complex $\left[\mathrm{Ni}(\mathrm{II})\left(\mathrm{L}^{1-}\right)_{3}\right]^{1-}$ presents an intense band at $591 \mathrm{~nm}, \varepsilon=2.4 \times 10^{3} \mathrm{~L} \mathrm{~mol}^{-1} \mathrm{~cm}^{-1}$. Beer's law is obeyed from 4.02 $\mathrm{x} 10^{-5}$ to $2.01 \times 10^{-4} \mathrm{~mol} \mathrm{~L}^{-1}$ with limits of detection and quantification of $4.15 \times 10^{-5} \mathrm{~mol} \mathrm{~L}^{-1}$ and $5.02 \times 10^{-5} \mathrm{~mol}$ $\mathrm{L}^{-1}$, respectively. The method was compared with atomic absorption spectrophotometry and inductively coupled plasma atomic emission spectroscopy obtaining good results. Cobalt and Titanium cause low interference in the method.

\section{INTRODUCTION}

Nickel determination is important in metallurgy, biological sciences and environmental analytical chemistry. There is a growing need for the development of analytical procedures with high sensitivity for nickel determination.

The usual methods for determination of nickel using chemical reagents like; dimethylglyoxime, sodium diethyldithiocarbamate, (ethylenedinitrilo) tetraacetica acid disodium salt (Titriplex ${ }^{\circledR}$ III), 2,2'-Furil dioxime and dithioxamide [1]. The dimethylglyoxime method present $\varepsilon=14 \times 10^{3} \mathrm{~L} \mathrm{~mol}^{-1} \mathrm{~cm}^{-1}$ at $450 \mathrm{~nm}$ and $\mathrm{Co}$, $\mathrm{Cr}(\mathrm{III}) \mathrm{Cu}(\mathrm{II}), \mathrm{Mn}(\mathrm{II}), \mathrm{Fe}$ and $\mathrm{Zn}$ higher $1 \mu \mathrm{g} \mathrm{mL} \mathrm{m}^{-1}$ interfere and it is advisable to isolate the nickel by extraction with dimethylglyoxime/chloroform before the determination in aqueous solution. The method involves the addition of various chemical reagents (hydrochloric acid, bromine water and ammonia) and the times stated for which addition are to be strictly adhered [2]. In the sodium diethyldithiocarbamate method $\mathrm{Cu}, \mathrm{Bi}, \mathrm{Co}$ and $\mathrm{Fe}$ are interferents and should be removed by the prior extraction with dimethylglyoxime. The method presents $\varepsilon=35 \times 10^{3} \mathrm{~L} \mathrm{~mol}^{-1} \mathrm{~cm}^{-1}$ but in ultra-violet region $(325$ $\mathrm{nm})$. The method is time consuming and use extractions with carbon tetrachloride [3]. The method using Titriplex® III gives a coloured complex utilized for determination of nickel by spectrophotometric observation of the band at $1000 \mathrm{~nm}$ [4]. The 2,2'-Furil dioxime forms with nickel a yellow, water insoluble complex which is extractable with chloroform and it can be utilized for photometric determination [5]. The method utilizing dithiooxamide is very sensitive (limit of detection about $0.01 \mu \mathrm{g}$ nickel) but copper and cobalt interfere seriously in the method [6].

Others analytical procedures have been proposed including voltammetry $[7,8]$, ion selective electrodes $[9,10]$, polarography [11], derivative spectrophotometry [12], fluorescence spectrometry [13,14] and inductively coupled plasma atomic emission spectroscopy ICP-AES $[15,16]$. The search for new chromogen- 
ic reagents for spectrophotometric methods is important because these methods have the advantages of simplicity, rapidity, low costs and wide application [17-23].

The chemical behaviors of nickel, iron and cobalt are very similar, and these elements are frequently found together in real samples, notably in metal alloys used to improve the material properties, for example, the mechanical and chemical resistance of steel. The Inox used in orthodontics has an austenitic structure, with a composition of $18 \%$ chromium, $8 \%$ nickel, and 0.08 to $0.15 \%$ carbon, the remaining content being iron. The chromium-cobalt alloy contains $40 \%$ cobalt, $20 \%$ chromium, $15 \%$ nickel, $15.8 \%$ iron, $7 \%$ molybdenum, $2 \%$ manganese, $0.16 \%$ carbon and $0.04 \%$ beryllium and its properties are very similar to those of the steel, however, with greater formability.

Catecholates, semiquinones and quinones are highly reactive dioxolenes, with important participation in biological structures performing essential functions in living organisms. The dioxolene molecules show interesting magnetic and redox behaviors, forming colorful complexes with heavy metals [24, 25]. Studies on the preparation and spectrophotometric (UV-Vis, IR, EPR and Raman) analysis of the Co(II), Ni(II), Zn(II) and $\mathrm{Fe}(\mathrm{III})$ water soluble compounds with dioxolene derived from dopamine oxidation in a sodium thiosulfate environment, have shown that L-dopa-semiquinone has a high affinity for the transition metals under study [26]. The compound resulting from the complexation reaction of the L-dopa-semiquinone and $\mathrm{Ni}$ (II) at a $\mathrm{pH}$ of 7 was proposed to be a soluble $\left[\mathrm{Ni}(\mathrm{II})\left(\mathrm{L}^{1-}\right)_{3}\right]^{1-}$ anion with the structure showed in Figure 1. The absorption spectrum shows an intense absorption band at $591 \mathrm{~nm}$ with $\varepsilon=2.4 \times 10^{3} \mathrm{~L} \mathrm{~mol}^{-1} \mathrm{~cm}^{-1}$, assigned to an inter-ligand charge transfer [26].

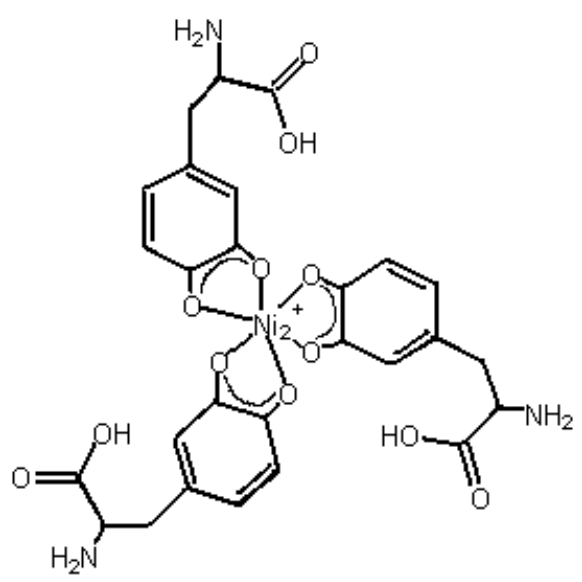

Figure 1. Proposed structure for the soluble [(Ni(II)(L1-)3]1- anion complex where L1- is the L-dopasemiquinone radical.
The aim of this study was to develop a UV-Vis spectrophotometric methodology for determination of $\mathrm{Ni}$ (II) using a new reagent, prepared from L-dopa, and to test it in the determination of $\mathrm{Ni}$ (II) in three commercial metallic alloys; Inox, nickel-titanium (Ni-Ti), and nickel-cobalt (Ni-Co). The results are compared with those of the established methods of atomic absorption spectroscopy (AAS) and inductively coupled plasma optical emission spectrometry (ICP-AES).

\section{EXPERIMENTAL}

Preparation of the chromogenic reagent (L-dopasemiquinone)

All of the solutions were prepared with ultra-pure water (Helga). Sodium thiosulfate $(0.3131 \mathrm{~g})$ (Aldrich Chemical 99.9\%) was dissolved in $500 \mathrm{~mL}$ of water $\left(3.9610^{-3} \mathrm{~mol} \mathrm{~L}^{-1}\right)$, following by $0.1008 \mathrm{~g}$ of L-dopa [(S)-2-amino-3-(3,4-dihydroxyphenyl) propanoic acid, $\left.\mathrm{C}_{9} \mathrm{H}_{11} \mathrm{NO}_{4}\right]$ (Aldrich Chemical 99.9\%) (1.06 $10^{-3} \mathrm{~mol} \mathrm{~L}^{-1}$ ) with $\mathrm{O}_{2}$ bubbling at a constant flow of 0.5 $\mathrm{L} \mathrm{min}^{-1}$. After 48 hours of reaction the absorption band at $278 \mathrm{~nm}$, a characteristic electronic transition of the L-dopa, disappeared and a band at $337 \mathrm{~nm}$, characteristic of the L-dopasemiquinona, emerged (Fig. 2). The resulting dark green solution was stored in polyethylene flasks at $4^{\circ} \mathrm{C}$.

\section{Stock solution of $\mathrm{NiCl}_{2}$}

A stock solution of $\mathrm{Ni}(\mathrm{II})$ was prepared dissolving nickel chloride (Aldrich Chemical 99.9\%) in water $\left(1.00 \times 10^{-3} \mathrm{~mol} \mathrm{~L}^{-1}\right)$. Aliquots were transferred to $25 \mathrm{~mL}$ volumetric flasks and completed with buffer solution $\mathrm{pH} 7.5\left(\mathrm{KH}_{2} \mathrm{PO}_{4} / \mathrm{NaOH}\right)$ resulting in solutions with concentrations of $4.02 \times 10^{-5}, 8.04 \times 10^{-5}, 1.206$ $\times 10^{-4}, 1.608 \times 10^{-4}$, and $2.01 \times 10^{-4} \mathrm{~mol} \mathrm{~L}^{-1}$. The solutions were standardized with EDTA. 


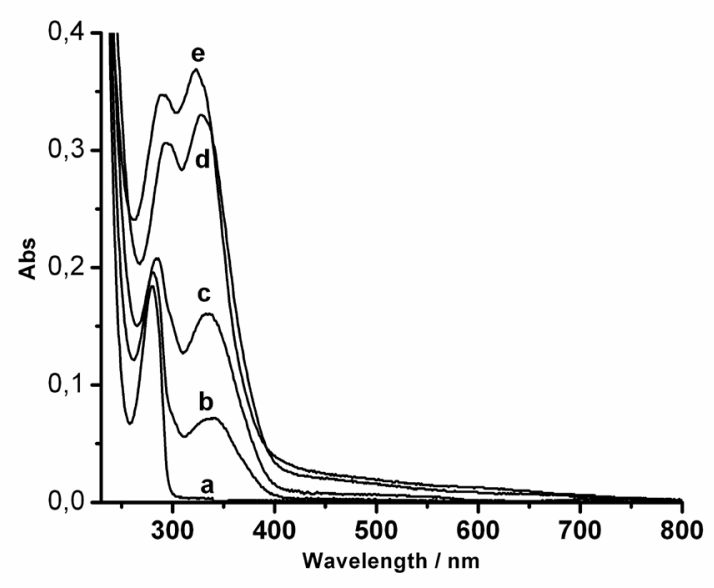

Figure 2. UV-Vis absorption spectra obtained during the reaction to obtain the chromogenic reagent (L-dopasemiquinone). Aqueous solution containing 1.06 10-3 mol L-1 L-dopa and 3.96 10-3 mol $\mathrm{L}-1$ of $\mathrm{Na} 2 \mathrm{~S} 2 \mathrm{O} 3$ with $\mathrm{O} 2$ bubbling at a constant flow of $0.5 \mathrm{~L}$ min-1. Reaction times (h): (a) 0; (b) 24; (c) 48; (d) 72; (e) 96.

\section{Obtaining the Analytical Curves}

The analytical curves $(n=5)(Y=-0.0572+$ $2483 \mathrm{X}, \mathrm{r}=0.998$ ) were obtained mixing $5 \mathrm{~mL}$ of the chromogenic solution with $5 \mathrm{~mL}$ of $\mathrm{Ni}$ (II) solution. A blank was obtained using $5 \mathrm{~mL}$ of buffer solution $\mathrm{pH}$ 7.5 and $5 \mathrm{~mL}$ of the chromogenic solution. The test tubes were sealed and the homogenized mixtures were placed in ultra-thermostatic bath at $25 \pm 0.01{ }^{\circ} \mathrm{C}$, for $30 \mathrm{~min}$. Aliquots $(3 \mathrm{~mL})$ were transferred to a quartz cuvette $(10 \mathrm{~mm})$ and the absorbances were measured at $591 \mathrm{~nm}$ (Thermo Scientific, Genesys 2).

\section{Determination of the Limits of Detection (LOD)} and Quantification (LOQ)

To seven test tubes were added $5 \mathrm{~mL}$ of buffer 7.5 and $5 \mathrm{~mL}$ of chromogenic solution. After 30 minutes at $25{ }^{\circ} \mathrm{C}$ the absorbances were measured at $591 \mathrm{~nm}$. The limit of detection (LOD) was calculated using the equation $\mathrm{LOD}=\mathrm{X}+3 \mathrm{~s}$, where $\mathrm{X}$ is the mean of the measured values and $s$ is standard deviations. The limit of quantification (LOQ) was determinate using the expression $\mathrm{LOQ}=\mathrm{X}+10 \mathrm{~s}$.
Samples of the metallic alloys ( $0.055 \mathrm{~g}$ of Inox, $0.035 \mathrm{~g}$ of $\mathrm{Co}-\mathrm{Cr}$ and $0.0135 \mathrm{~g}$ of Ni-Ti) were digested in $10 \mathrm{~mL}$ of aqua regia solution $(3: 1 \mathrm{HCl}: \mathrm{H}-$ $\mathrm{NO}_{3}$ ) at $105 \pm 5{ }^{\circ} \mathrm{C}$. Two blanks containing all reagents but not including the samples, accompanied the alloys digestion. After complete digestion, the resulting solutions were maintained under heating until they were almost dried. The obtained residues were redissolved with water and completed up to $50 \mathrm{~mL}$ in volumetric flasks.

For the spectrophotometric determination of $\mathrm{Ni}(\mathrm{II})$ in the alloys, $1 \mathrm{~mL}$ of the digested solution of Inox was transferred to $100 \mathrm{~mL}$ volumetric flask and for the $\mathrm{Co}-\mathrm{Cr}$ or $\mathrm{Ni}-\mathrm{Ti} 2 \mathrm{~mL}$ of the digested solutions were transferred for $25 \mathrm{~mL}$ of volumetric flask and the volumes completed with buffer solution $\mathrm{pH}$ 7.5.

The procedure for the spectrophotometric determination of $\mathrm{Ni}$ (II) followed the same procedure used to obtain the analytical curve. The analytical curve $\mathrm{Y}$ $=-0.0572+2483 X(n=5)$ was used to determinate the $\mathrm{Ni}(\mathrm{II})$. Aliquots of the same solutions of $\mathrm{Ni}(\mathrm{II})$ were used to determine $\mathrm{Ni}$ (II) using atomic absorption atomic spectrophotometry (AAS) and inductively coupled plasma (ICP-AES).

\section{Study of Interference from Metals}

After the determination of the best conditions for the complexation reaction between $\mathrm{Ni}$ (II) and dopa-semiquinone, the possibility of interference from the transition metals $\mathrm{Co}, \mathrm{Cr}, \mathrm{Cu}, \mathrm{Fe}, \mathrm{Mn}, \mathrm{Cd}$, $\mathrm{Pb}$ and $\mathrm{Zn}$ in the determination of $\mathrm{Ni}$ (II) was studied. The solutions used in the interference studies to determinate $8.04 \times 10^{-5} \mathrm{~mol} \mathrm{~L}^{-1}$ of $\mathrm{Ni}$ (II) were prepared by the addition of aliquots of $1000 \mathrm{mg} \mathrm{L}^{-1}$ standard solutions of $\mathrm{Cr}(\mathrm{III}), \mathrm{Co}(\mathrm{II}), \mathrm{Cu}(\mathrm{II}), \mathrm{Fe}(\mathrm{III}), \mathrm{Mn}(\mathrm{II})$, $\mathrm{Zn}(\mathrm{II}), \mathrm{Cd}(\mathrm{II}), \mathrm{Pb}$ (II) (Merck) and $\mathrm{Zn}$ (II) (Carlo Erba) with a $7.5 \mathrm{pH}$ buffer. The solution of $\mathrm{Ni}$ (II) with the interfering metal was prepared adding to a test tube 5 $\mathrm{mL}$ of the nickel solution, $5 \mathrm{~mL}$ of the metal interfering solution and $5 \mathrm{~mL}$ of the chromogenic solution. The mixture was maintained at $25^{\circ} \mathrm{C}$ by 30 minutes. A blank was prepared in the same conditions with $5 \mathrm{~mL}$ of buffer pH 7.5 and $5 \mathrm{~mL}$ of chromogenic solution. Aliquots of $3 \mathrm{~mL}$ were transferred to a quartz cuvette 
$(10 \mathrm{~mm})$ and the absorbances measured at $591 \mathrm{~nm}$. All experiments were carrying out in duplicates.

A study on the interference of anions was also performed. Solutions $110^{-3} \mathrm{~mol} \mathrm{~L}^{-1}$ of salicylate, nitrate, carbonate, sulfate, citrate, tartrate, oxalate and acetate were prepared from their sodium salts. To $25 \mathrm{~mL}$ volumetric flasks were added $2 \mathrm{~mL}$ of $1.00 \mathrm{x}$ $10^{-3} \mathrm{~mol} \mathrm{~L}^{-1} \mathrm{NiCl}_{2}$, the anion solutions and completed with buffer $\mathrm{pH} 7.5$. Aliquots of $5 \mathrm{~mL}$ of the solution were mixed with $5 \mathrm{~mL}$ of chromogenic solution at $25^{\circ} \mathrm{C}$ for 30 minutes. A blank was prepared using $5 \mathrm{~mL}$ of buffer pH 7.5 without the anions. Several solutions for each anion were prepared growing the concentration until to observe interference in $\mathrm{Ni}$ (II) determination. All the experiments were made in duplicates.

\section{Nickel Determination by Atomic Spectroscopy} (AAS and ICP-OES)

The determination of $\mathrm{Ni}(\mathrm{II})$ in the metallic alloys by AAS (Shimadzu AA-6601F) was carried out using a nickel hollow cathode lamp and atomic transition at $232 \mathrm{~nm}$. The analytical curve from $8.50 \times 10^{-6}$ to $4.25 \times 10^{-5} \mathrm{~mol} \mathrm{~L}^{-1}$ was obtained diluting $1.70 \times 10^{-2} \mathrm{~mol} \mathrm{~L}^{-1}$ of $\mathrm{Ni}(\mathrm{II})$ stock solution previously standardized with EDTA.

The ICP-AES (Perkin Elmer Optima 5200DV) analysis was performed with the same solutions used for the spectrophotometric and AAS methods with the quantification limits of: $\mathrm{Fe}\left(0.0012 \mathrm{mg} \mathrm{L}^{-1}\right), \mathrm{Ni}(0.0018$ $\left.\mathrm{mg} \mathrm{L}{ }^{-1}\right)$, Co (0.0015 $\left.\mathrm{mg} \mathrm{L}^{-1}\right)$, Ti (0.001 $\left.\mathrm{mg} \mathrm{L}^{-1}\right)$ and $\mathrm{Cr}$ (0.0019 $\left.\mathrm{mg} \mathrm{L}^{-1}\right)$. The analytical curves were obtained using the $1000 \mathrm{mg} \mathrm{L}^{-1}$ standard solutions for each metal from 0.1 to $10.0 \mathrm{mg} \mathrm{L}^{-1}$.

\section{RESULTS AND DISCUSSION}

The complex formed between $\mathrm{Ni}$ (II) and the chromogenic reagent, formulated as the soluble anion $\left[\mathrm{Ni}(\mathrm{II})\left(\mathrm{L}^{1-}\right)_{3}\right]^{1-}($ Fig. 1) presents an intense interligand charge transfer at $591 \mathrm{~nm}\left(\varepsilon=2.4 \times 10^{3} \mathrm{~L} \mathrm{~mol}^{-1} \mathrm{~cm}^{-1}\right)$ resulting in an intense blue coloration ( Fig. 3 ) [26]. The complex is stable at $\mathrm{pH} 7.5$ and $25^{\circ} \mathrm{C}$. The best reaction parameters for obtaining higher absorbance values were determined using a $2^{4}$ factorial design.

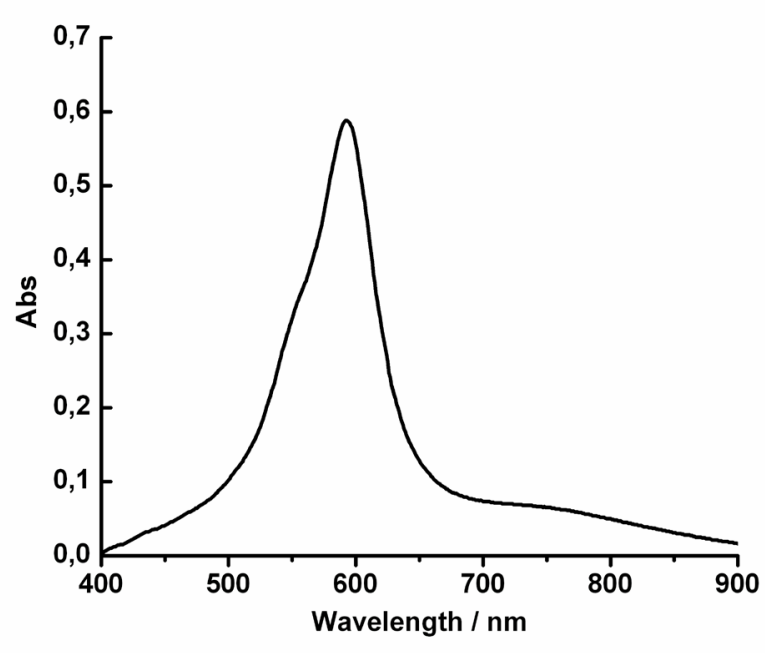

Figure 3. UV-Vis absorption spectrum of the complex [(Ni(II)(L1)3]1- formed in aqueous solution, $\mathrm{pH} 7.5$ (buffer $\mathrm{KH} 2 \mathrm{PO} 4 / \mathrm{NaOH}$ ), temperature of $25 \stackrel{\circ}{ } \mathrm{C}$, reaction time of 30 minutes and 1.16 10-4 mol L-1 of $\mathrm{Ni}(\mathrm{II})$.

The results showed that the effects of reaction time, $\mathrm{pH}$ and concentration of nickel were significant for obtaining high absorbance (analytical signal). The analytical signal increased at higher $\mathrm{pH}$ values and concentration of $\mathrm{Ni}$ (II) and shorter reaction times. It was verified that the analytical signal showed little variation with temperature, and therefore a temperature of $25{ }^{\circ} \mathrm{C}$ was used for subsequent experiments. The results of the factorial design, with the temperature fixed at $25{ }^{\circ} \mathrm{C}$, showed that the best reaction conditions in terms of the analytical signal were: 30 minutes of reaction time, $\mathrm{pH} 7.5$ and $\mathrm{Ni}$ (II) concentration range of $1.00 \times 10^{-5}$ to $2.00 \times 10^{-5} \mathrm{~mol} \mathrm{~L}^{-1}$.

The limits of detection and quantification of the method were $4.15 \times 10^{-5} \mathrm{~mol} \mathrm{~L}^{-1}$ and $5.02 \times 10^{-5}$ mol L-1 respectively. The maximum concentrations $\left(\mathrm{mol} \mathrm{L}^{-1}\right)$ of metals that can be present without interfering in the determination of $\mathrm{Ni}(\mathrm{II})$ were: $6.81 \times 10^{-7}$ for $\mathrm{Co}(\mathrm{II}), 7.65 \times 10^{-7}$ for $\mathrm{Cr}(\mathrm{III}), 8.10 \times 10^{-8}$ for $\mathrm{Cu}(\mathrm{II})$, $6.50 \times 10^{-8}$ for $\mathrm{Mn}(\mathrm{II}), 1.23 \times 10^{-6}$ for $\mathrm{Zn}(\mathrm{II}), 6.00 \times 10^{-7}$ for $\mathrm{Fe}(\mathrm{III}), 1.07 \times 10^{-4}$ for $\mathrm{Cd}(\mathrm{II}), 5.74 \times 10^{-5}$ for $\mathrm{Pb}(\mathrm{II})$. The salicylate, nitrate, carbonate, sulfate, citrate, tartrate, oxalate and acetate anions do not cause interference until they are present in the same concentration as the $\mathrm{Ni}(\mathrm{II})$ to be determined, in the case studied this being $8.04 \times 10^{-5} \mathrm{~mol} \mathrm{~L}^{-1}$.

One of the major problems with spectrophotometric methods for $\mathrm{Ni}$ (II) determination is cobalt interference, because many of the reagents used when working with nickel also react with cobalt. In general, this interference is eliminated by procedures involv- 
ing operations such the extraction, ion exchange and precipitation of nickel with dimethylglyoxime. However, the methodology developed has a very low level of interference from $\mathrm{Co}(\mathrm{II})$, being significant only at ca. $7.0 \times 10^{-7} \mathrm{~mol} \mathrm{~L}^{-1}$, corresponding to $0.04 \mathrm{mg} \mathrm{L}^{-1}$. Table 1 gives the recovery test results for $\mathrm{Ni}$ (II) in very complex samples (orthodontic alloys). ICP-AES analysis was used to determine the major elements contained in the alloys, and it showed the complexity of the samples. The following contents were found (mass percentage, \%): $69.4 \% \mathrm{Ni}$ and $30.6 \%$ Ti for the $\mathrm{Ni}-\mathrm{Ti}$ alloy; $8.97 \% \mathrm{Ni}, 73.0 \% \mathrm{Fe}$ and $18.3 \%$ Co for the Inox; and $18.0 \% \mathrm{Ni}, 15.8 \% \mathrm{Fe}, 45.4 \% \mathrm{Co}$ and $20.8 \%$ $\mathrm{Cr}$ for the Co-Cr alloy.

Table 1. Mass percentage (\%) of $\mathrm{Ni}(\mathrm{II})$ in metallic alloys determinate by the spectrophotometric, Atomic Absorption Spectrophotometry (AAS) and Inductively Coupled Plasma Atomic Emission Spectroscopy (ICP-AES) methods.

\section{CONCLUSION}

The results obtained showed that the spectrophotometric method is sensitive, fast, can be used at room temperature $\left(25^{\circ} \mathrm{C}\right.$ ) and does not require solvent extraction. The preparation of the new chromogenic is simple and safe, and complex experimental procedures or equipment are not needed. The study of metal interferences showed that $\mathrm{Mn}$ (II) and $\mathrm{Cu}$ (II) interfere more significantly, whereas the traditionally most problematic metal in terms of interference in nickel determination, that is, cobalt, showed low interference. The methodology was tested on real complex samples, Inox, Ni-Ti and Co-Cr alloys, and good results were obtained.

\begin{tabular}{|c|c|c|c|}
\hline Alloy & Spectrophotometric ${ }^{1}$ & $\mathrm{AAS}^{2}$ & ICP-AES $^{3}$ \\
\hline Inox & $11 \pm 3$ & $9.7 \pm 0.5$ & 9 \\
\hline $\mathrm{Ni}-\mathrm{Ti}$ & $72 \pm 8$ & $76 \pm 1.1$ & 70 \\
\hline $\mathrm{Co}-\mathrm{Cr}$ & $16 \pm 1.5$ & $18 \pm 0.6$ & 21 \\
\hline
\end{tabular}

The results were compared to those obtained with AAS and ICP-AES, two very widely used methodologies, and the results showed that the spectrophometric method was able to quantify $\mathrm{Ni}(\mathrm{II})$ in alloys, including the $\mathrm{Co}-\mathrm{Cr}$ alloy, which presents high levels of the cobalt. The results indicated that the other elements that comprise the alloys did not interfere to a great extent in the determination of $\mathrm{Ni}(\mathrm{II})$.

\section{REFERENCES}

[1] J. Fries, H. Getrost, Organic reagents for trace analysis, E. Merck Darmstadt, 1977.

[2] H. Specker, H. Kartkamp, Z. Anal. Chem. 145 (1955) 260 
[3] O. R. Alexander, E. M. Godar, N. J. Linde, Ind. Eng. Chem. Anal. Ed. 18 (1946) 206.

[4] L. D. Brake, W. M. McNabb, J. F. Hazel, Anal. Chim. Acta 19 (1958) 42.

[5] A. R Gabler, A. M. Mitchel, M. G Mellon, Anal. Chem. 23 (1951) 500.

[6] W. D. Jacobs, J. H.Yoe, Anal. Chim. Acta, 20 (1959) 332.

[7] M. Korolczuk, Talanta, 53 (2000) 679.

[8] D.V.Vukomanovic, J. A. Page, G. W. Vanloon, Anal. Chem. 68 (1996) 829.

[9] V. K. Gupta, R. Prasad, P. Kumar, R. Mangla, Anal. Chim. Acta 420 (2000) 19.

[10] A. Abbaspour, A. Izadyar, Microchem. J. 69 (2001) 7.

[11] H. B.Mark, D. Koran, L. Gierst, J. Electroanal. Chem. 498 (2001) 228.

[12] S. L. C. Ferreira, A. C. S. Costa, D. S. deJesus, Talanta 43 (1996) 1649.

[13] V. Rigin, Anal. Chim. Acta 283 (1993) 895.

[14] O. W. Lan, S. Y. Ho, Anal. Chim. Acta 280 (1993) 269.

[15] T. Kempf, M. Sonneborn, Mikrochim. Acta. 2 (1983) 445.

[16] J. L. Fernandez-Turiel, J. F. Llorens, F. Lopez-Vera, C. Gomez-Artola, I. Morell, D. Gimeno, Fresenius J. Anal. Chem. 368 (2000) 601.

[17] S. Zhao, X. Xia, Q. Hu, Anal. Chim. Acta 39 (1999) 365.

[18] K. Ohshita, H. Wada, G. Nakagawa, Anal. Chim. Acta 140 (1982) 291.

[19] A. Izquierdo, J. Carrasco, Analyst 109 (1984) 605.

[20] Q. Hu, G. Yang, Z. Huang, J. Yin, Anal. Sci. 19 (2003) 1449.
[21] S. K. Kumar, P. S. Rao, L. Krishnaiah, B. Jayaraj, P. Chiranjeevi, Anal. Sci. 20 (2004) 951.

[22] Z. J. Li, J. M. Pan, J. Tang, Anal. Lett. 35 (2002) 167.

[23] Y. Liu, X. Chang, S. Wang, Y. Guo, B. Din, S. Meng, Talanta 64 (2004) 160.

24]. U. ElAyaan, E. Herlinger, R. F. Jameson, W. Linert, J. Chem. Soc., Dalton Trans., (1997) 2813 (1997).

[25]. R. C. Hider, B. Howlin, J. R. Miller, A. R. MohdNor, J. Silver, Inorg. Chim. Acta, 80 (1983), 51(1983).

[26] W. J. Barreto, R. A. Ando, P. S. Santos, W. P. Silva, Spectrochim. Acta A 68 (2007) 612. 